Review

\title{
The Change from Past to Future for Adsorbent Materials in Treatment of Dyeing Wastewaters
}

\author{
George Z. Kyzas ${ }^{1,2, *}$, Jie Fu ${ }^{3}$ and Kostas A. Matis ${ }^{1}$
}

1 Laboratory of General \& Inorganic Chemical Technology, Department of Chemistry, Aristotle University of Thessaloniki, Thessaloniki GR 541 24, Greece; E-Mail: kamatis@chem.auth.gr

2 Department of Petroleum and Natural Gas Technology, Technological Educational Institute of Kavala, Kavala GR 654 04, Greece

3 Environmental Engineering Program, Department of Civil Engineering, Auburn University, Auburn, AL 36849, USA; E-Mail: jzf0017@auburn.edu

* Author to whom correspondence should be addressed; E-Mail: georgekyzas@ gmail.com; Tel.: +30-2310-997807; Fax: +30-2310-997859.

Received: 22 September 2013; in revised form: 27 October 2013 / Accepted: 2 November 2013 / Published: 8 November 2013

\begin{abstract}
Adsorption is one of the most promising decolorization techniques in dyeing wastewater treatment. Adsorption techniques for wastewater treatment have become more popular in recent years owing to their efficiency in the removal of pollutants too stable for biological methods. Dye adsorption is a result of two mechanisms (adsorption and ion exchange) and is influenced by many factors as dye/adsorbent interaction, adsorbent's surface area, particle size, temperature, $\mathrm{pH}$, and contact time. The main advantage of adsorption recently became the use of low-cost materials, which reduces the procedure cost. The present review firstly introduced the technology process, research history and research hotspot of adsorption. Then, the application of adsorption in treatment of dyeing wastewaters in the past decades was summarized, revealing the impressive changes in modes, trends, and conditions. From this review article, the different philosophy of synthesis of adsorbent materials became evident.
\end{abstract}

Keywords: adsorption; dyeing wastewater; sustainability; past; future 


\section{Introduction}

A first obvious change from past to present, where the things began to change, was the discovery of synthetic dyes. Cheaper to produce, brighter, more colors - fast and easy to apply to fabric are some of the characteristic of those new dyes. Scientists have competed to formulate gorgeous new colors, and synthetic dyes had become obsolete for most applications. No doubt, this bright colored material has changed the world; however, the chemicals used to produce dyes are often toxic, carcinogenic, or even explosive [1]. Among the different pollutants of aquatic ecosystem, dyes are a major group of chemicals [2-5]. Many industries like textiles, leather, cosmetics, paper, printing, plastics, etc., use many synthetic dyes to color their products. Thus, effluents from these industries contain various kinds of synthetic dyestuffs. For instance dyes used in the textile industries are classified into three classes: (a) anionic (direct, acid, and reactive dyes); (b) cationic (all basic dyes); and (c) non-ionic (dispersed dyes). Basic and reactive dyes are extensively used in the textile industry because of their favorable characteristics of bright color, being easily water soluble, cheaper to produce, and easier to apply to fabric [6-8].

Over 100,000 commercially available dyes exist and more than 700,000 t per year are produced annually $[9,10]$. Due to their good solubility, synthetic dyes are common water pollutants and they may frequently be found in trace quantities in industrial wastewater. An indication of the scale of the problem is given by the fact that two per cent of dyes that are produced are discharged directly in aqueous effluent $[9,11]$. Due to increasingly stringent restrictions on the organic content of industrial effluents, it is necessary to eliminate dyes from wastewater before it is discharged. Many of these dyes are also toxic, and even carcinogenic, and this poses a serious hazard to aquatic living organisms [12,13]. However, wastewater containing dyes is very difficult to treat, as the dyes are recalcitrant organic molecules, resistant to aerobic digestion, and are stable to light, heat, and oxidizing agents $[14,15]$.

The most studied dye classes, in the dye bearing effluent treatment, are reactive and basic [16-18]. The dye loss from the dyeing process to the effluent is estimated $10 \%-50 \%$ for reactive dyes and $0-5 \%$ for basic ones [19]. Given that reactive and basic dyes could simultaneously exist in the equalization tank of a dye-house, it is of fundamental importance to remove both of them [20]. The research on dyeing wastewater treatment has been often focused on reactive dyes for three main reasons: (i) reactive dyes represent an increasing market share, because they are used to dye cotton fibers, which makes up about half of the world's fiber consumption; (ii) a large fraction, typically around $30 \%$ of the applied reactive dyes, is wasted due to the dye hydrolysis in alkaline dye bath; and (iii) conventional wastewater treatment plants have a low removal efficiency for reactive and other anionic soluble dyes, which leads to colored waterways [17,21].

The presence of color and color-causing compounds has always been undesirable in water for any use. It is, therefore, not at all surprising to note that the color in wastewater has now been considered as a pollutant that needs to be treated before discharge. Thus, color removal is one of the most difficult requirements to be faced by the textile finishing, dye manufacturing, pulp and paper industries, among others. These industries are major water consumers and are, therefore, a source of considerable pollution. In order to implement an appropriate treatment process, it is of utmost importance to minimize pollution, and to do that, it is necessary to know its exact nature. Robinson et al. [11] attempted to give some collective information related to current available technologies and have suggested an effective, cheaper alternative for dye removal and decolorization applicable on large 
scale. They have also provided some important data related to the desorption of individual textile dyes and a synthetic dye effluent from dye-adsorbed agricultural residues using solvents [22,23], which is also important.

Adsorption technique for wastewater treatment has become more popular in recent years owing to their efficiency in the removal of pollutants too stable for biological methods. Dye adsorption is a result of two mechanisms (adsorption and ion exchange) and is influenced by many factors, such as dye/adsorbent interaction, adsorbent's surface area, particle size, temperature, $\mathrm{pH}$, and contact time. The main advantage of adsorption recently became the use of low-cost materials, which reduces the procedure cost.

According to a brief screening in Scopus, numerous results were exported for the term "dye adsorption" (Figure 1). The major peak for this process was observed in 21 st century. The present review firstly introduced the technology process, research history, and hotspot of adsorption. Their application in dyeing wastewater was then described in details. Major conclusions were exported for the differences of procedures during decades, which strongly influenced by new trends and economic aspects of each time-period. All of these confirmed the sustainability of adsorption techniques. Another point of interest is the different philosophy of adsorbent materials used during the last decades, becoming obvious, and the turn to low-cost materials.

Figure 1. Works published for "dye adsorption” terms (Data after search in Scopus).

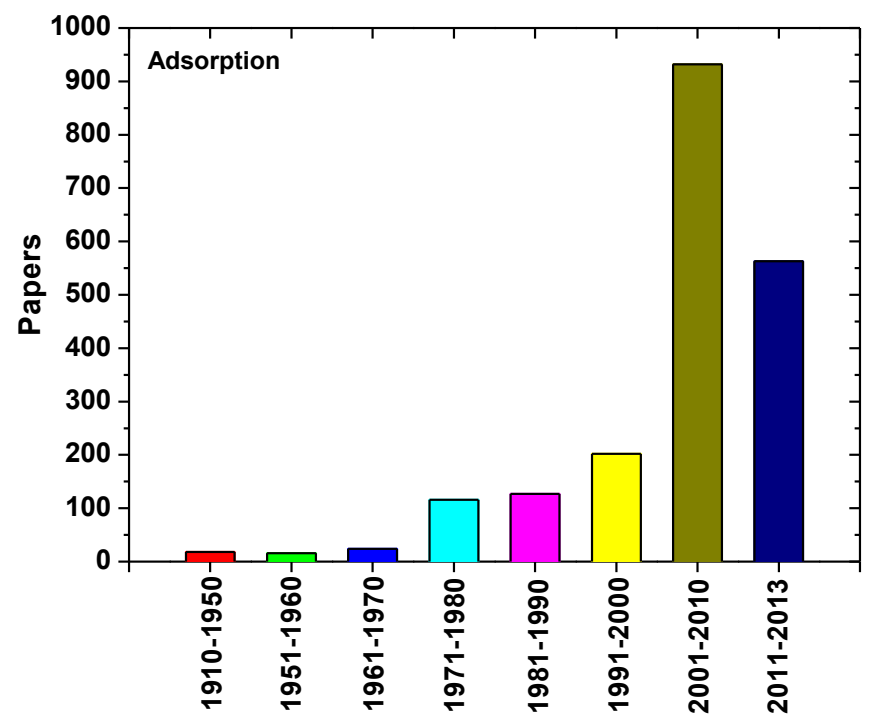

\section{Adsorbents for Dyeing Wastewaters}

Adsorption has been applied either in a single mode, mainly for dyes removal from simulated/synthetic wastewaters, or in a combinational mode for total cleaning of real wastewaters. Recently, other materials, more economical, have been attempted to be used as adsorbents at the tertiary stage of effluent's treatment, replacing the activated carbon: natural materials, biosorbents, waste materials from industry and agriculture, clay materials (bentonite, kaolinite), zeolites, siliceous material (silica beads, alunite, perlite), agricultural wastes (bagasse pith, maize cob, rice husk, coconut shell) [24-26], industrial waste products (waste carbon slurries, metal hydroxide sludge, coffee wastes) [24,27-29], biosorbents (chitosan, peat, biomass), and others (starch, cyclodextrin, cotton) [24,30]. In particular, for the treatment of textile 
wastewater, the most promising proposed technique was to lead the effluents from dyeing reactor to adsorption columns instead of an equalization tank [30] (Figure 2).

Figure 2. Treatment of textile wastewaters [30].

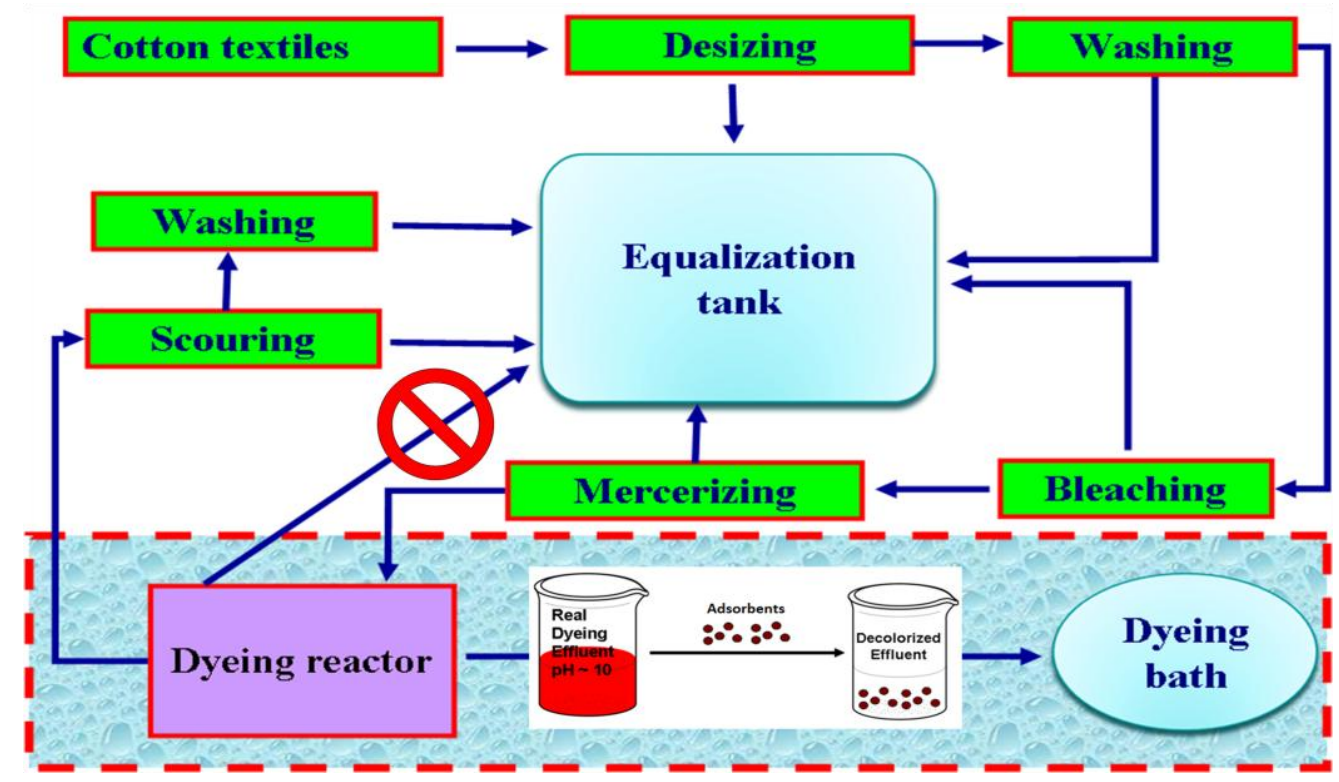

\section{Change from Past to Future}

\subsection{First Attempts (1910-1950)}

A first published paper for dye adsorption was in 1912, when Chapman and Siebold [31] attempted to separate particular dye molecules with adsorption techniques. However, that study was more in the analytical (and not technological) field given the limited knowledge. Furthermore, dyes were removed from solutions with growing crystal of sodium nitrate as materials, lead nitrate and barium nitrate in continuous 10-year studies [32,33]. A more particular study investigated the removal of wool violet 4BN from lead sulfate, giving acidity $(\mathrm{pH})$ optimum conditions [34]. Based on previous knowledge, Gibby and Argument [35] studied the adsorption/interactions of Methylene Blue, Congo Red, Bordeaux Extra, Indigo Carmine, and Solway Ultra Blue using, as adsorbent materials, some mercury interfaces. It presented that the adsorption passed through a maximum as the concentration increased and the adsorption was calculated with Gibbs's equation.

\subsection{Initial Knowledge (1951-1970)}

Based on the knowledge from previous years for dye adsorption, Ewing and Liu [36] studied the adsorption of crystal violet and Orange II from aqueous solutions on anatase, rutile, and zinc oxide. The nature of the adsorbent materials used began to differ and promoted some oxides. It was found that up to nine days of agitation were required to attain true equilibrium, and that high temperatures hastened the process. The adsorption has been found to be physical in nature. Whetstone [37] studied the importance of dye adsorption in crystal habit modification phenomena. Studies of modified crystals were realized, in which dye adsorption followed by overgrowth of dye molecules. Haldeman and Emmett [38], investigated the specific adsorption of the alkyl orange dyes on silica gels prepared in the presence of those dyes. 
The results confirmed that silica gel samples had a specific adsorptive capacity for the particular alkyl orange present during the gel preparation. The specificity gradually disappeared when the gels are stored at room temperature. Prasad and Dey [39] made a more thermodynamic study for dye adsorption, calculating the heats of adsorption of Congo Red and Fuchsine by using various samples of hydrous thorium oxide. The order of the heats of adsorption was in conformity with the order of the specific adsorption of the dyes by the samples.

The change in studies from the initial years of dye adsorption research to the future would be more intensely indicated by Brooks [40], who explained the mechanism of Methylene Blue adsorption from aqueous solutions, in quite different adsorbent systems, as common siliceous minerals found in petroleum reservoir formations. Three minerals (montmorillonite, kaolinite, and silica-sand flour) were prepared so that all the cec (cation exchange capacities) sites on the mineral surfaces were occupied by sodium. Methylene Blue dye adsorption isotherms were measured on these three minerals prepared in the sodium form. Other studies [41,42] showed she isotherms of some cyanine dyes adsorbed on surfaces of silver-halide precipitates. The specific areas of the precipitates were derived from measurements of the adsorption of argon and of benzene vapor. It was found that a given cyanine dye did not necessarily adsorb with the same area per molecule for conditions of saturation on each of the surfaces of silver chloride, bromide, and iodide. A first approach to porous and ceramic adsorbent materials was attempted in 1969 by Davis et al. [43], who described the dye adsorption on the surfaces of untreated and pretreated ceramic raw materials. These ceramic materials have not been used before, so the challenge would be very interesting. The adsorption of dye on alumina, bone, ceramic colors, and flint could be related to the specific surface areas. Porous materials such as flint exhibit a hysteresis effect, which was manifestly a difference in the rates of adsorption and of desorption.

\subsection{Economic Development (1971-2000)}

During this period, many changes were realized regarding the adsorption of model dyes from aqueous solutions. New materials, new parameters, and, in general, a novel philosophy of adsorption were developed. Iyer et al. [44] presented results of an experimental investigation in which effects of electrolytes in the aqueous dyebath on the various surfaces were studied. In experiments, the anionic direct dye Chlorazol Sky Blue FF was used for dyeing samples of viscose rayon, amorphous titanium dioxide, silica (aerosil), graphene, and activated charcoal. Adsorption thermodynamic parameters of samples tested were determined as function of electrolyte concentration. A first approach on dyeing wastewaters was done by Rock and Stevens [45], studying a combined process involving adsorption on synthetic polymer and ion exchange. The process had several operating and performance advantages over activated carbon adsorption. A more complete works was realized in 1975 by Sethuraman and Raymahashay [46], performing experiments to study the kinetics of adsorption of two industrial dyes [Methylene Blue (cationic) and Sulfur Blue (anionic)] by kaolinite and montmorillonite clays. The cationic dye was removed from aqueous solution at a continuously decreasing rate from 10 to $0.07 \mathrm{mg} \cdot \mathrm{g}^{-1} \mathrm{~min}^{-1}$ by montmorillonite whereas kaolinite adsorbed the dye at a faster and uniform rate of $16 \mathrm{mg} \cdot \mathrm{g}^{-1} \cdot \mathrm{min}^{-1}$. The anionic dye was removed at a uniform rate of $2.3 \mathrm{mg} \cdot \mathrm{g}^{-1} \cdot \mathrm{min}^{-1}$ by kaolinite and $2.6 \mathrm{mg} \cdot \mathrm{g}^{-1} \cdot \mathrm{min}^{-1}$ by montmorillonite. 
Given the economic boom of this period, other parameters began to be taken into consideration apart from the clearly scientific ones ( $\mathrm{pH}$, kinetics, capacity etc.). Therefore, Mitchell et al. [47] investigated the effectiveness of dye removal from textile wastewaters using low-cost activated carbons produced from various solid wastes. A first turn to economic low-cost materials was attempted. In some instances, activated carbons produced from solid wastes could be effectively used to remove residual dye from waste water. The effectiveness of dye removal by activated carbons produced from solid wastes varied from excellent, with carbon produced from peanut hulls, to poor, with carbon produced from pine bark. Basic and direct dye solutions were reduced to less than 1 ppm concentration using activated carbon produced from peanut hulls. Until then, activated carbon adsorption appeared to be the most effective and economical tertiary treatment method for removal of organics, including dyes. Potential sources of low cost activated carbon were agricultural, industrial, and municipal solid wastes. Further work of real industrial dyeing wastewaters was done by McKay [48], who studied the ability of Filtrasorb 400 activated carbon to absorb Astrazone Blue (basic) and Telon Blue (acidic) dyes using batch equilibrium and fluidized beds. The carbon adsorbed between $30 \%$ and $80 \%$ of its own weight of dye at equilibrium depending on dyestuff type and adsorbent particle size. The effects of adsorbent particle size and dye flow rates were also studied in fluidized bed systems. A detailed study of the adsorption of Telon Blue dye on carbon has been also undertaken using fixed beds, and the data correlated into a design model using the bed depth service time (BDST) method of analysis [49]. In this time-period, emphasis was given by many researchers to the study of diffusion phenomena of dye molecules onto adsorbents during procedure [50-53].

\subsection{1st Century}

\subsubsection{Activated Carbon}

Amongst all the adsorbent materials proposed in 21st century, activated carbon is the most popular for the removal of pollutants from wastewater [54,55]. In particular, the effectiveness of adsorption on commercial activated carbon for removal of a wide variety of dyes from wastewaters has made it an ideal alternative to other expensive treatment options [55]. Due to their great capacity to adsorb dyes, activated carbons are considered to be the most effective adsorbent. This capacity is mainly due to their structural characteristics and their porous texture, which gives them a large surface area, and their chemical nature, which can be easily modified by chemical treatment in order to increase their properties. Some of the main examples of wastewaters decolorization with activated carbon are given below.

The adsorption capacity of activated carbon depends on various factors, such as surface area, pore size distribution, and surface functional groups on the adsorbent, polarity, solubility, and molecular size of the adsorbate, solution $\mathrm{pH}$ and the presence of other ions in solution, and so on. The most widely used activated carbons are microporous and have high surface areas, and as a consequence, show high efficiency for the adsorption of low molecular weight compounds and for larger molecules. An adsorption study of Methylene Blue (MB) on activated carbon fiber (ACF) was also carried out. It has been used in adsorption systems, including removal of noxious gases, due to its extensive specific surface area, high adsorption capacity, well-developed micropores, reproducibility, and processability. The effects of various experimental parameters, such as the initial MB concentration and the ACF 
mass, on the adsorption rates were investigated. Equilibrium data was fit well by a Freundlich isotherm equation. Adsorption measurement shows that the process is very fast [56]. Nakagawa et al. [57] made attempt to evaluate the porous properties and hydrophobicity of activated carbons obtained from several solid wastes, namely, waste PET (polyethylene terephthalate), waste tires, refuse derived fuel, and wastes generated during lactic acid fermentation from garbage. Activated carbons having various pore size distributions were obtained by the conventional steam-activation method and via the pretreatment method (i.e., mixture of raw materials with a metal salt, carbonization, and acid treatment prior to steam activation). The liquid-phase adsorption characteristics of organic compounds from aqueous solution on the activated carbons were determined to confirm the applicability of these carbons, where reactive dye (Reactive Black 5) was employed as representative adsorbate. Authors reported that the activated carbons with plentiful mesopores, prepared from PET and waste tires, had quite a high adsorption capacity for large molecules. Therefore, they are useful for wastewater treatment, especially for removal of bulky adsorbates. Li et al. [58] reported the displacement of atrazine by the strongly competing fraction of natural organic matter (NOM) in batch and continuous-flow powdered activated carbon (PAC) adsorption systems. The extent of atrazine displacement by NOM was found to be dependent on the type of PAC, while the rate of displacement was a function of PAC type as well as carbon dose. Choy et al. [59] reported the adsorption of three acidic dyes, Acid Blue 80 (AB 80), Acid Red 114 (AR 114), and Acid Yellow 117 (AY 117) onto activated carbon. In the same paper, they have also reported the adsorption isotherms for the three single components (AB 80, AR 114, AY 117) and three binary components (AB $80+$ AR 114, AB $80+$ AY 117, AR 114 + AY 117), dyes' adsorption on activated carbon. Four models for predicting the multi-component equilibrium sorption isotherms have been compared in order to determine the best to predict or correlate binary adsorption data. These four models are the extended Langmuir isotherm, the simplified model based on single-component equilibrium factors, a modified extended Langmuir isotherm with a constant interaction factor, and a modified extended Langmuir isotherm incorporating a surface coverage - dependent interaction factor. Adsorption of trichloroethylene (TCE) by two ACFs and two granular activated carbons pre-loaded with hydrophobic and transphilic fractions of NOM were examined by Karanfil et al. [60]. In addition, the kinetics and mechanism of MB adsorption on commercially activated carbon and indigenously prepared activated carbons from bamboo dust, coconut shell, groundnut shell, rice husk, and straw have been reported by Kannan et al. [61]. The contributions of Jirankova et al. [62] deal with study of the combined adsorption-membrane process for organic dye removal. Adsorption equilibrium and kinetics of Egacid red sorption on PAC were studied in batch experiments. Tapered bed adsorption columns, using activated carbon, have been used to study the removal of two organic pollutants, an acid dye, and parachlorophenol, from aqueous effluent by McKay et al. [63]. Equilibrium sorption isotherms were measured to provide the saturation capacity $\left(\mathrm{Q}_{\mathrm{e}}\right)$ of each pollutant by Chemviron Filtrasorb 400 carbon, for operating continuous adsorption columns. The Redlich-Peterson (R-P) isotherm gives the best-fit model to describe the sorption process of these organic pollutants. The conventional bed depth service time (BDST) model has not been applied to tapered beds before, as the linear velocity of fluid is continually changing along the column. Several others authors $[64,65]$ have also tested activated carbon for the adsorption of various dyes. Pereira et al. [66] reported that the surface chemistry of a commercially activated carbon has been selectively modified, without changing significantly its textural properties, by means of chemical 
treatments, using $\mathrm{HNO}_{3}, \mathrm{H}_{2} \mathrm{O}_{2}, \mathrm{NH}_{3}$, and thermal treatments under a flow of $\mathrm{H}_{2}$ or $\mathrm{N}_{2}$, and they found that the surface chemistry of the activated carbon plays a key role in dye adsorption performance. For cationic dyes (basic), the acid oxygen-containing surface groups show a positive effect but thermally treated samples still present good performances, showing the existence of two parallel adsorption mechanisms involving electrostatic and dispersive interactions. The conclusions obtained for each dye individually were confirmed in the color removal from a real textile process effluent.

Another source of activated carbon is agricultural waste. A very detailed review of Demirbas [67] and Sharma [68] reported some plentiful agricultural waste and various unused plant parts which offered an inexpensive and renewable additional source of activated carbon (AC). These waste materials have little or no economic value and often pose great disposal problems. Thus, these waste materials are used in treated and untreated forms for the removal of dyes. A wide variety of activated carbon prepared from agro-waste such as pine wood, corn cob, fruit stones, nut shells, cassava peel, tapioca peel, bamboo, bagasse, rice husk, bark, leaves, and used tea leaves are described by Sharma [68].

Application of activated carbon prepared from rice husk, was estimated as a potential adsorbent for the removal of Malachite Green and found to have good adsorption capacity comparative to the activated carbon prepared from banana peel [69], date pits [70], rice husk [61], wood saw dust [71], orange peel [69], and sugarcane dust [72]. Garg et al. [73] demonstrated that the adsorption efficiency of sulphuric acid treated saw dust was higher than formaldehyde treated saw dust for the removal of malachite green. It was concluded that ACR (activated carbon) adsorption efficiency was unaffected by $\mathrm{pH}$, while $\mathrm{pH}=6-9$ was optimum for dye removal by SDC (sulphuric acid treated sawdust carbon) and SD (sawdust). The adsorption of ash prepared from rice husk was found to be an effective adsorbent because of its high surface area and the volume. The maximum monolayer capacity estimated was $690 \mathrm{mg} / \mathrm{g}$. Moreover the adsorption was maximum on the ash compared to the activated carbon prepared from the rice husk after calcinations because of the presence of both silica and carbon. The adsorption characteristics of Direct Red 23 (DR 23) on to mangrove bark (Rhizopus apiculata), that has been previously treated with formaldehyde in acid medium, was investigated and observed that dye sorption decreases at high $\mathrm{pH}$ values in accordance with the ion exchange mechanism of the adsorption and maximum removal was at 2 . The monolayer sorption capacity of modified bark for Direct Red 3 (DR 3) sorption was found to be $21.55 \mathrm{mg} / \mathrm{g}$.

However, activated carbon presents several disadvantages [27]. It is quite expensive, the higher the quality the greater the cost, non-selective, and ineffective against disperse and vat dyes. The regeneration of saturated carbon is also expensive, not straightforward, and results in loss of the adsorbent. The reactivation or the regeneration of activated carbons involves restoring the adsorptive capacity of saturated activated carbon by desorbing adsorbed contaminants on the activated carbon surface.

The most common regeneration technique employed in industrial processes is thermal reactivation [74]. The thermal regeneration process generally follows three steps [75]: (i) adsorbent drying at approximately $105{ }^{\circ} \mathrm{C}$; (ii) high temperature desorption and decomposition $\left(500-900{ }^{\circ} \mathrm{C}\right.$ ) under an inert atmosphere; and (iii) residual organic gasification by an oxidizing gas (steam or carbon dioxide) at elevated temperatures $\left(800^{\circ} \mathrm{C}\right)$.

The heat treatment stage utilizes the exothermic nature of adsorption and results in desorption, partial cracking and polymerization of the adsorbed organics. The final step aims to remove charred organic residue formed in the porous structure in the previous stage and re-expose the porous carbon 
structure, regenerating its original surface characteristics. After treatment, the adsorption column can be reused. Per adsorption-thermal regeneration cycle between 5 and $15 \mathrm{wt} \%$ of the carbon bed is burnt off, resulting in a loss of adsorptive capacity [76]. Thermal regeneration is a high energy process due to the high required temperatures, making it both an energetically and commercially expensive process [75]. Plants that rely on thermal regeneration of activated carbon have to be of a certain size before it is economically viable to have regeneration facilities onsite. As a result, it is common for smaller waste treatment sites to ship their activated carbon cores to a specialized facility for regeneration, increasing the process' already significant carbon footprint [77].

Current concerns with the high energy/cost nature of thermal regeneration of activated carbon have encouraged research into alternative regeneration methods to reduce the environmental impact of such processes. Though several of the regeneration techniques cited have remained areas of purely academic research, some alternatives to thermal regeneration systems have been employed in industry. Current alternative regeneration methods are: (i) chemical and solvent regeneration [78]; (ii) microbial regeneration [79]; (iii) electrochemical regeneration [80]; ultrasonic regeneration [81]; and (iv) wet air oxidation [82].

\subsubsection{Chitosan-Based Adsorbents}

There is abundant literature concerning the evaluation of adsorption performances of raw chitosan, especially in terms of adsorption capacity (amount of dye adsorbed) or uptake. In a batch system, the determination of the dye uptake rate by a chitosan-based material is often based on the equilibrium state of the adsorption system. At least 100 dyes, mainly anionic dyes, have been so far studied. Chitosan has an extremely high affinity for many classes of dyes. In particular, it has demonstrated outstanding removal capacities for anionic dyes such as acid, reactive, and direct dyes. This is due to its unique polycationic structure. The effectiveness of chitosan for its ability to interact with dyes has been studied by numerous workers. Juang and co-workers [83-85] demonstrated the usefulness of chitosan for the removal of reactive dyes. They found that the maximum adsorption capacities of chitosan for RR 222 (reactive red), RB 222 (reactive blue), and RY 145 (reactive yellow) were 1653, 1009, and $885 \mathrm{mg} / \mathrm{g}$, respectively [84]. Annadurai [86-88] and Crini et al. [89] also reported that chitosan may be a useful adsorbent for the effluent of textile mills because of its high adsorption capacity. Uzun and Guzel [90-93] noted that chitosan can be used in the study of dyestuff adsorption in comparison with most other adsorbents. This polysaccharide showed a higher capacity for adsorption of dyes than CAC (commercial activated carbon) and other low-cost adsorbents, as reviewed by Crini [94]. Kim and Cho [95] also indicated that the amount of RB 5 adsorbed on chitosan beads is much greater than on CAC. Similar conclusions were reached by Lima et al. [96] for BB 9 (basic blue) adsorption. McKay's group [97-99] recently published a series of papers on the ability of chitosan to act as an effective adsorbent for the removal of acid dyestuffs from aqueous solution. The monolayer adsorption (saturation) capacities were determined to be 973.3, 922.9, 728.2, and $693.2 \mathrm{mg}$ of dye per gram of chitosan for AO 12 (acid orange), AO 10 (acid orange), AR 73 (acid red), and AR 18 (acid red), respectively [97]. The interaction between chitosan and anionic dyes has also been intensively investigated by Guibal and co-workers [100-103]. Their investigations clearly indicated that chitosan had a natural selectivity for dye molecules and was very useful for the treatment of wastewater. They 
reported that adsorption capacities ranged between 200 and $2000 \mathrm{mmol} / \mathrm{g}$ for chitosan and between 50 and $900 \mathrm{mmol} / \mathrm{g}$ for CAC [102]. They concluded that chitosan exhibited a twofold, or more, increase in the adsorption capacity compared to $\mathrm{CAC}$ in the case of acid, direct, reactive, and mordant dyes. The best choice for the adsorbent between CAC and chitosan depends on the dye, however, it was impossible to determine a correlation between the chemical structure of the dye and its affinity for either carbon or chitosan.

However, a strong advantage of chitosan is its modification ability. The basic idea of modifications is to make various changes in chitosan structure to enhance its properties (capacity, resistance, etc.). In particular, several researchers have proposed certain modifications in chitosan backbone to improve its adsorption capacity. These modifications are realized with grafting reactions [89,104]. The modifications can improve chitosan's removal performance and selectivity for dyes, alter the physical and mechanical properties of the polymer, control its diffusion properties, and decrease the sensitivity of adsorption to environmental conditions. Many scientists suggested chemical grafting specific ligands [105,106]. However the only class for which chitosan [107] has low affinity is basic (cationic) dyes. To overcome this problem, the use of $N$-benzyl mono and disulfonate derivatives of chitosan is suggested to enhance its cationic dye hydrophobic adsorbent properties and to improve its selectivity [89,104]. These derivatives could be used as hydrophobic adsorbents in acidic media without any cross-linking reactions. To enhance and further develop the high potentials of chitosan, it is necessary to add/introduce chemical substituents at a specific position in a controlled manner [107]. This chemical derivatization promotes new adsorption properties, in particular towards basic dyes in acidic medium or reactive/acid dyes in basic medium. Another study deals with the enzymatic grafting of carboxyl groups onto chitosan as a mean to confer the ability to adsorb basic dyes on beads [107]. The presence of new functional groups on the surface of beads results in increased surface polarity and density of adsorption sites and hence improved adsorption selectivity for the target dye. Other studies showed that the ability of chitosan to selectively adsorb dyes could be further improved by chemical derivatization. Novel chitosan-based materials with long aliphatic chains are developed by reacting chitosan with high fatty acids and glycidyl moieties [108]. In this way, these products could be used as effective adsorption materials for both anionic and cationic dyes. Other researchers suggested the use of cyclodextrin — grafted chitosan derivatives as new chitosan derivatives for the removal of dyes [109,110]. These materials are characterized by a rate of adsorption and a global efficiency greater than that of the parent chitosan polymer [107].

The pure form of chitosan powders (raw) tends to present some disadvantages, such as unsatisfactory mechanical properties and poor heat resistance. Another important limitation of the pure form is its solubility in acidic media and, therefore, it cannot be used as an insoluble adsorbent under these conditions (except after physical and chemical modification). The main technique to overcome these limitations is to transform the raw polymer into a form in which physical characteristics are more attractive. So, cross-linked beads have been developed and proposed. After cross-linking, these materials maintain their properties and original characteristics [111], particularly their high adsorption capacity, although this chemical modification results in a decrease in the density of free amine groups at the surface of the adsorbent in turn lowering polymer reactivity towards metal ions [100,101]. The cross-linking agent is very important. Therefore many researchers studied the chitosan behavior prepared with different cross-linkers, such as glutaraldehyde (GLA), tripolyphosphate sodium (TPP), 
epichlorydrine (EPI), ethylene glycol diglycidyl ether (EGDE), etc. [18,20,112,113]. The change in adsorption capacity was confirmed; the results showed that the chitosan-EPI beads presented a higher adsorption capacity than GLA and EGDE [20,113]. They reported that these materials can be used for the removal of reactive, direct, and acid dyes. It was found that $1 \mathrm{~g}$ chitosan adsorbed 2498, 2422, 2383, and $1954 \mathrm{mg}$ of various reactive dyes (Reactive Blue 2; Reactive Red 2; Direct Red 81; and Acid Orange 12, respectively) [18]. As a comparison, it is specified that the adsorption capacities of commercially activated carbon for reactive dyes generally vary from 280 to $720 \mathrm{mg} / \mathrm{g}$. Another advantage of EPI is that it does not eliminate the cationic amine function of the polymer, which is the major adsorption site to attract the anionic dyes during adsorption [113]. The cross-linking with GLA (formation of imine functions) or EDGE decreases the availability of amine functions for the complexation of dyes. With a high cross-linking ratio the uptake capacity decreases drastically. Among the conditions of the cross-linking reaction that have a great impact on dye adsorption is the chemical nature of the cross-linker, as mentioned above, and also the extent of the reaction. In general, the adsorption capacity depends on the extent of cross-linking and decreases with an increase in cross-linking density. When chitosan beads were cross-linked with GLA under heterogeneous conditions, it was found that the saturation adsorption capacity of reactive dyes on cross-linked chitosan decreased exponentially from 200 to $50 \mathrm{mg} / \mathrm{g}$ as the extent of cross-linking increased from 0 to $1.5 \mathrm{~mol}$ GLA per mol of amine. This is due to the restricted diffusion of molecules through the polymer network and reduced polymer chain flexibility. In addition, the loss of amino-binding sites by reaction with aldehyde is another major factor in this decrease. However, the cross-linking step was necessary to improve mechanical resistance, to enhance the resistance of material against acid, alkali, and chemicals, and also to increase the adsorption abilities of chitosan. According to literature [18,20,112,113], the adsorption capacity of non cross-linked beads was greater than that of cross-linked beads in the same experimental conditions. The materials, mainly cross-linked using GLA, have been also proposed as effective dye adsorbents by several researchers $[109,111]$. The reaction of chitosan with GLA leads to the formation of imine groups, in turn leading to a decrease in the number of amine groups, resulting in a lowered adsorption capacity, especially for dyes adsorbed through ion-exchange mechanisms. Furthermore, it is noted that cross-linking can change the crystalline nature of chitosan, as suggested by the X-ray diffraction (XRD) diffractograms. After the cross-linking reaction, there was a small increase in the crytallinity of the chitosan beads and also increased accessibility to the small pores of the material.

It is evident from this brief literature survey that chitosan can be utilized as an interesting tool for the purification of dye-containing wastewater because of its outstanding adsorption capacity.

\subsubsection{Low-Cost Agricultural Wastes as Adsorbents}

There have been many attempts to find inexpensive and easily available adsorbents to remove pollutants such as agricultural solid wastes where, according to their physicochemical characteristics and low cost, they may be good potential adsorbents [114]. Agricultural productions are available in large quantities around the world; thus large amounts of waste are rejected. Table 1 shows agricultural production (ton/year) in some countries. Agricultural wastes are lignocellulosic materials that consist of three main structural components, which are lignin, cellulose, and hemicelluloses. These components 
contribute mass and have high molecular weights. Lignocellulosic materials also contain extractive structural components, which have a smaller molecular size [67]. Agricultural wastes are renewable, available in large amounts and are less expensive as compared to other materials used as adsorbents. Agricultural wastes are better than other adsorbents because agricultural waste is usually used without or with a minimum of processing (washing, drying, grinding) and, thus, reduce production costs by using a cheap raw material and eliminating energy costs associated with thermal treatment [115]. There are specific alternative agricultural by-products used intensely as dye adsorbents, such as peanut hull, coir pith, and rice husk, as listed in Table 1, which shows previous studies of the adsorption of different dyes using adsorbents based on agricultural solid wastes.

Table 1. Previous studies of the adsorption of dyes using adsorbents based on agricultural solid wastes.

\begin{tabular}{ccc}
\hline Adsorbent & Dye & Reference \\
\hline Sugar beet pulp & Gemazol turquoise blue-G & {$[116]$} \\
Powdered peanut hull & Sunset yellow, Amaranth, Fast green & {$[117]$} \\
Rice husk ash & Indigo Carmine & {$[118]$} \\
Chemically modified peanut hull & Methylene Blue, Brilliant cresyl blue, Neutral red, Sunset & {$[119]$} \\
Peanut hull & yellow, Fast green & {$[120]$} \\
Coir pith activated carbon & Methylene Blue, Brilliant cresyl blue, Neutral red & {$[121]$} \\
Coir pith activated carbon & Reactive Orange 12, Reactive Red 2, Reactive Blue 4 & {$[3]$} \\
Coir pith carbon & Congo Red & {$[122]$} \\
ZnCl $l_{2}$ activated coir pith carbon & Methylene Blue & {$[123]$} \\
Coir pith & Acid brilliant blue, Acid violet, Methylene Blue, & {$[71]$} \\
Rice husks activated carbon & Rhodamine B & {$[124]$} \\
Rice husk-based porous carbon & Acid violet & {$[125]$} \\
Rice husk & Malachite green & {$[126]$} \\
Tea waste & Malachite green & {$[127]$} \\
Coniferous pinus bark powder & Congo Red & {$[128]$} \\
Orange peel activated carbon & Methylene Blue & {$[129]$} \\
Neem sawdust & Crystal violet & {$[130]$} \\
Guava seed carbon & Direct Blue-106 & {$[131]$} \\
Peanut hull & Malachite green & {$[132]$} \\
Loofa activated carbon & Acid blue 80 & {$[133]$} \\
Apricot stone activated carbon & Reactive Black 5 & {$[134]$} \\
Almond shells & Reactive orange & {$[135]$} \\
Lemon peel & Astrazon yellow 7 GL & {$[136]$} \\
Bagasse fly ash & Direct red 80 & {$[137]$} \\
Polygonum orientale Linn activated & Malachite green & {$[138]$} \\
\hline & Methyl violet & Malachite green \\
\hline
\end{tabular}




\subsubsection{Fungi, Bacteria, Algae}

Three novel-trendy categories of recent literature for the decolorization of dyeing wastewaters with adsorption are fungi, bacteria, and algae [139].

A wide variety of fungal organisms are capable of decolorizing a wide range of dyes [140,141]. Many genera of fungi have been employed either in living or inactivated form. The use of white-rot fungi such as Phanerochaete chrysosporium in decolorizing textile wastewater has been widely reported in literature [142-149]. There are various fungi other than white-rot fungi, such as Aspergillus niger [141,150,151], Rhizopus arrhizus [152], Rhizopus oryzae [153], which can also decolorize and/or biosorb diverse dyes. For living cells, the major mechanism is biodegradation because they can produce lignin modifying enzymes, laccase, manganese peroxidase (MnP), and lignin peroxidase $(\mathrm{LiP})$, which due to their unspecific activity are the first step in the process of mineralization of dyes [154]. The relative contributions of LiP, MnP, and laccase to the decolorization of dyes may be different for each fungus. In addition to biodegradation, a biosorption mechanism might also play an important role in the decolorization of dyes by living fungi. For dead cells, the mechanism is biosorption, which involves physicochemical interactions such as adsorption, deposition, and ion exchange. Decolorization of dye wastewater by fungal biomass has been extensively reviewed by Fu and Viraraghavan [140], Kaushik and Malik [155], and Singh [156]. Limited information is available on interactions between dead fungal biomass and a variety of dyes with complex molecular structures. Fu and Viraraghavan [157] studied the roles played by functional groups such as carboxyl, amino, phosphate, and lipid fractions present in fungal biomass from Aspergillus niger in the biosorption of four different dyes. In the biosorption of Basic Blue 9 on Aspergillus niger, carboxyl and amino groups were found to be the main binding sites while in biosorption of Acid Blue 29, only the amino group was a major site, and electrostatic attraction was believed to be the primary mechanism. In the biosorption of Congo Red, the amino, carboxylic acid, phosphate groups, and lipid fractions were all found to be important binding sites and, in addition to electrostatic attraction, other mechanisms were also believed to be involved in biosorption. In the biosorption of Disperse Red 1, physical and chemical adsorption along with electrostatic attraction was found to be the mechanism of biosorption while amino group and lipid fractions were the major binding sites.

Most research has focused on studying the biodegradation/decolorization potential of bacteria [158] and less attention has been paid to employing dead bacterial biomass for biosorption of dyes. In 2005, Won et al. [159] identified Corynebacterium glutamicum as a potential biosorbent of Reactive Red 4, which can bind $104.6 \mathrm{mg} / \mathrm{g}$ at $\mathrm{pH}$ 1. Two general types of bacteria exist, Gram-positive and gram-negative. Gram-positive bacteria are comprised of a thick peptidoglycan layer connected [160,161] by amino acid bridges. Embedded in the Gram-positive cell wall are polyalcohols, some of which are lipid linked to form lipoteichoic acids. The cell wall of Gram-negative bacteria is thinner, and composed of only 10\%-20\% peptidoglycan [162]. In addition, the cell wall contains an additional outer membrane composed of phospholipids and lipopolysaccharides. The mode of solute uptake by dead/inactive cells is extracellular; the chemical functional groups of the cell wall play vital roles in biosorption. Biodegradation processes may be anaerobic, aerobic, or involve a combination of the two. The ability of actinomycetes, particularly Streptomyces species, to decolorize and degrade textile dyes has been widely investigated. In a study by $\mathrm{Hu}$ [163], three Gram-negative bacteria (Aeromonas sp.; 
Pseudomonas luteola; and Escherichia coli), two Gram-positive bacteria (Bacillus subtilis and Staphylococcus aureus) and activated sludge (consisting of both gram-negative and gram-positive bacteria) were used as biosorbents for the removal of reactive dyes such as Reactive Blue, Reactive Red, Reactive Violet, and Reactive Yellow. Dead cells of test genera showed a higher uptake than living cells due to an increased surface area and gram-negative bacteria had a higher adsorption capacity than gram-positive bacteria due to higher lipid contents in the cell wall portion. The mode of solute uptake by dead/inactive cells is extracellular, and the chemical functional groups of the cell wall play vital roles in biosorption. Functional groups present on the bacterial cell wall include carboxyl, phosphonate, amine and hydroxyl groups [164]. Several dye molecules, which exist as dye cations in solutions, are also attracted towards carboxyl and other negatively charged groups. In addition, amine groups adsorb anionic dyes via electrostatic interaction or hydrogen bonding. Vijayaraghavan and Yun [165] observed that the amine groups of Corynebacterium glutamicum were responsible for the binding of reactive dye anions via electrostatic attraction. Carboxyl, amine, phosphonate, sulfonate, and hydroxyl groups have become well established as being responsible for dye binding.

Algae have been found to be potential biosorbents because of their availability in both fresh and saltwater. The biosorption capacity of algae is attributed to their relatively high surface area and high binding affinity. Cell wall properties of algae play a major role in biosorption; electrostatic attraction and complexation are known to take place during algal biosorption [166]. Functional groups such as hydroxyl, carboxylate, amino, and phosphate, found on the algal cell surface, are considered to be responsible for sequestration of contaminants from wastewater. The dye removal, especially by using algae, may be attributed to the accumulation of dye ions on the surface of algal biopolymers and further to the diffusion of the dye molecules from the aqueous phase to the solid phase of the biopolymer [167]. Extracellular polymers consist of surface functional groups, which enhance sorption of the dye molecules onto the surface of the polymer (floc) during the dye removal process $[168,169]$. The released metabolic intermediates (long chain biopolymers), which have excellent coagulation capacity, along with the dye remaining in the aqueous phase, tend to adsorb onto the surface of the polymers and settle (biocoagulation) [169]. Mohan et al. [169] studied the removal of Reactive Yellow 22 dye by active Spirogyra sp. and reported that the dye removal mechanism can be explained by biosorption, bioconversion, and biocoagulation. While, removal of Acid Red 274 dye using an inactivated Spirogyra rhizopus system was attributed to biosorption and biocoagulation [167]. A study by Ozer et al. [167] revealed the potential ability of the algae Spirogyra rhizopus to decolorize synthetic wastewaters containing initial concentration of dye Acid Red 274 from 25 to 1000 mg/L. Almost complete removal of Acid Red 274 dye from synthetic wastewater, with a final concentration lower than $25 \mathrm{mg} / \mathrm{L}$, was achieved by using Spirogyra rhizopus resulting from biocoagulation and biosorption.

\subsubsection{Nanomaterials}

A relatively new category of adsorbents (especially regarding their size) is nanomaterials. After 1995, some attempts were achieved in order to prepare and use these nanosized materials to decolorize effluents or simply remove dyes from aqueous systems.

A raw attempt was done by $\mathrm{Wu}$ and co-workers [170], who investigated the adsorption of several anionic dyes on nanosized alumina-modified silica particles of different compositions. Those silica 
cores had the same surface properties as alumina dispersed in aqueous solutions. Khan et al. [171]. studied the synthesis of nanoscale zero valent iron (NZVI) and tested it for the purification of waste water contaminated by basic blue 3 dye. In other study [172], nanoporous silica (NPS), with an average pore diameter of $2.4 \mathrm{~nm}$ and a surface area of $949 \mathrm{~m}^{2} / \mathrm{g}$, was synthesized by using nonyl phenol ethoxylated decylether (NP-10) and ethyl silicate 40\% (ETS-40) under acidic conditions. Ionic liquid functionalized adsorbent was prepared by grafting of $N$-methyl- $N$ '-propyltrimethoxysilylimidazolium chloride onto NPS for removal of methyl orange. Furthermore, Mahmodi used nickel ferrite nanoparticle (NFN) as dye nanomaterial [173]. The surface modification of NFN using sodium dodecyl sulfate (SDS) was studied. Dye removal ability of NFN and surface modified NFN (NFN-SDS) was investigated. Basic Blue 41 (BB 41), Basic Green 4 (BG 4), and Basic Red 18 (BR 18) were used as model compounds. The maximum dye adsorption capacity was $0.50 \mathrm{mg} / \mathrm{g}$ (BB 41), $0.41 \mathrm{mg} / \mathrm{g}$ (BG 4), and $0.25 \mathrm{mg} / \mathrm{g}$ (BR 18) for NFN and $111 \mathrm{mg} / \mathrm{g}$ (BB 41), $17 \mathrm{mg} / \mathrm{g}$ (BG 4), and $44 \mathrm{mg} / \mathrm{g}$ (BR 18) for NFN-SDS. Zhai et al. [174] reported the electrochemical synthesis of porous $\operatorname{Pr}(\mathrm{OH})_{3}$ nanobelt arrays (NBAs), nanowire arrays (NWAs), nanowire bundles (NWBs), and nanowires (NWs), and their applications as dye absorbents in water treatment. These $\operatorname{Pr}(\mathrm{OH})_{3}$ nanostructures exhibited high efficient and selective adsorption of the dyes with amine $\left(-\mathrm{NH}_{2}\right)$ functional groups such as Congo Red, Reactive Yellow, and Reactive Blue.

Liu and Zhang [175] studied the adsorption properties of nanoclays (activated clays by acid-treatment or calcinations, organic-modified clays with small molecules or polymers) for the adsorption and removal of organic dyes from aqueous solutions. In general, clays are natural environment-friendly materials with high specific surface area and are now widely used for the adsorption and removal of the organic pollutants.

A study of Cheung et al. [176] was based on the preparation of nanochitosan emulsion in a suspension form by adding tripolyphosphate solution into a chitosan solution drop-wise. The adsorption capacities of four acid dyes, namely, Acid Orange 10 (AO 10), Acid Orange 12 (AO 12), Acid Red 18 (AR 18), and Acid Red 73 (AR 73) on nanochitosan, have been determined to be 1.77, 4.33, 1.37, and $2.13 \mathrm{mmol} / \mathrm{L}$, respectively. The nanochitosan dye capacities were compared with normal chitosan capacities, which were 1.54, 2.66, 1.11, and 1.25 mmol/L for AO 10, AO 12, AR 18, and AR 73, respectively. In all cases, the nanochitosan has a higher capacity. A combination of chitosan and cyclodextrin was also probable as reported in other study [177]. Magnetic $\beta$-cyclodextrin-chitosan/graphene oxide materials (MCCG) were fabricated through a facile chemical route, and their application as excellent adsorbents for Methylene Blue (MB) removal were also demonstrated.

Another field of nanomaterials are the effects of magnetism. One of the first attempts to the concept of magnetic nano-dye-adsorbents was introduced by Liao et al. [178], who prepared them by covalently binding polyacrylic acid onto $\mathrm{Fe}_{3} \mathrm{O}_{4}$ magnetic nanoparticles, possessing high ion-exchange capacity and was successfully used for the fast removal of crystal violet. Another study reported the adsorption (and desorption) of Congo Red (CR) onto maghemite nanoparticles $\left(\gamma-\mathrm{Fe}_{2} \mathrm{O}_{3}\right)$ [179]. The adsorption capacity was evaluated using both the Langmuir and Freundlich adsorption isotherm models. Maghemite nanoparticles $\left(\gamma-\mathrm{Fe}_{2} \mathrm{O}_{3}\right)$ were prepared easily in a surfactant-less microemulsion by co-precipitation method. Deng et al. [180] studied the synthesis of magnetic graphene oxide (MGO) and its use as an adsorbent for simultaneous removal of $\mathrm{Cd}$ (II) and ionic dyes including Methylene Blue (MB) and Orange G (OG). In mono-component system, the maximum sorption capacities in ultrapure water for MB and OG were 64.23 and $20.85 \mathrm{mg} / \mathrm{g}$, respectively. Furthermore, 
adsorption of seven different organic dyes from aqueous solutions onto magnetite nanoparticles loaded tea waste (MNLTW) was studied by Madrakian and co-workers [181]. MNLTW was prepared via a simple method and was fully characterized. Adsorption characteristics of the MNLTW adsorbent was examined using Janus Green, Methylene Blue, Thionine, Crystal Violet, Congo Red, Neutral Red, and Reactive Blue 19 as adsorbates. Dyes adsorption process was thoroughly studied from both kinetic and equilibrium points of view for all adsorbents. Ge et al. [182] explored the removal of cationic dyes (Crystal Violet, Methylene Blue, and Alkali Blue 6B) from water solution by adsorption with magnetic nanoparticles (MNPs) modified with 3-aminopropyltriethoxysilane and copolymers of acrylic acid and crotonic acid. In another study [183], a graphene-based magnetic nanocomposite was synthesized and used as an adsorbent for the removal of a dye (Fuschine) from aqueous solutions.

In addition, nanocarbons were recently reported as dye adsorbents. Gong and co-workers [184] dealt with magnetic multi-wall carbon nanotube (MMWCNT) nanocomposites. They were synthesized and used as adsorbents for removal of cationic dyes from aqueous solutions. The MMWCNT nanocomposite was composed of commercial multi-wall carbon nanotubes and iron oxide nanoparticles. Adsorption characteristics of the MMWCNT nanocomposite adsorbent were examined using Methylene Blue, neutral red and brilliant Cresyl Blue as adsorbates. Experiments were carried out to investigate adsorption kinetics, adsorption capacity of the adsorbent and the effect of adsorption dosage and solution $\mathrm{pH}$ values on the removal of cationic dyes. Mishra and co-workers [185] functionalized multiwalled carbon nanotubes (f-MWNTs) for the adsorption (decolorization) of three different azoic dyes. Multiwalled carbon nanotubes (MWNTs) were synthesized by chemical vapor deposition (CVD) technique and purified by air oxidation and acid treatment. Maximum adsorption capacity of 148, 152, and $141 \mathrm{mg} / \mathrm{g}$ was obtained for direct Congo Red, Reactive Green HE4BD, and Golden Yellow MR dyes, respectively.

Apart from the common nanoadsorbents, nanoporous agricultural wastes were also reported for decolorization. In a study by Jayarajan et al. [186], the effect of agricultural waste product nano-porous adsorbent of Jack fruit peel waste for removing dye Rhodamine dye (Rd) from aqueous solution was investigated. The effect of adsorption isotherm were studied by carrying out a series of isotherm at different adsorbent dosages $(1,2$, and $3 \mathrm{~g} / \mathrm{L})$, temperatures $\left(30,40\right.$, and $\left.60{ }^{\circ} \mathrm{C}\right)$ and $\mathrm{pH}(4.95,8.14$, and 9.74), respectively. The adsorption equilibrium data were analyzed by using various adsorption isotherm models and the results have shown that adsorption behavior of the dye could be described reasonably well by Langmuir and Freundlich models. The characteristic parameters for each isotherm have been determined. The monolayer adsorption capacity determined was reasonably high $(\mathrm{g} / \mathrm{L})$ at adsorbent dosage $4.361(\mathrm{~g} / \mathrm{L})$, temperature $2.8496(\mathrm{~g} / \mathrm{L})$ and $\mathrm{pH} 4.3614(\mathrm{~g} / \mathrm{L})$ for adsorption of $\mathrm{Rd}$ dye, respectively. The monolayer adsorption capacity was determined to be 4.361 to $1.98 \mathrm{mg} / \mathrm{g}$.

\subsection{Future Plans}

The main advantage of adsorption technique is the opportunity to improve the nature and properties of adsorbent particles used. The trend of recent research leads to the application of cost-effective materials, which can adequately adsorb the dyes from solutions even presenting slightly lower capacities. The need of the market is to limit the procedure costs regarding the environmentally-friendly nature of the techniques suggested. For this purpose, significant emphasis will be given to green technology, using 
low-cost materials (agricultural wastes or by-products). There are already many works on this field, which are expected to be further improved.

The main drawback of the already published dye-adsorption studies is that their use is still in the laboratory stage, mostly without pilot studies or commercialization. Limited attempts for detailed economic and market analyses are available [139]. There is still reluctance in opting for non-viable immobilized biomass-based systems compared to the use of biological reactors with living cells, although the advantages of the former systems are well established. Some attempts have been realized in the past at commercializing immobilized biomass dye biosorbents such as Alga-Sorb, AMT-Bioclaim, B.V. Sorbex's biosorbents, and Bio-fix, but none have made a successful commercial entry in the market [187-189]. Peat is considered as the most successful biosorbent for use in either a natural state or in a modified form; however it is not regarded as the best biomaterial for commercialization because it is a finite resource and it is also not available everywhere in the world [188].

The main future target of market is to move the dye adsorption process to an industrial scale. It is relatively less difficult to demonstrate it in a laboratory; it is a little more challenging to demonstrate it at a pilot scale, but to really increase it to a large scale would call for a significant financial and technological effort. This mismatch between scientific progress in biosorption research (biosciences) and stagnation in industrial technology innovation needs to be corrected through translational research and technology transfer with a push for commercialization of research. Universities can play an active role in this process through a more formalized approach to technology transfer and protection of intellectual property $[139,190]$.

\section{Conclusions}

Adsorption as technique for dye adsorption was traced back in 1912. Numerous combinations between adsorbents and dye molecules were tested in order to obtain an effective material for industrial applications. From the past to the future, the nature of adsorbents used was significantly changed. From some inorganic hydroxides and crystals of 1950s, we passed to complex polymeric materials and carbons in 1990s, and now a trend to low-cost agricultural-based adsorbents. The key-factor of each dye adsorbent of the past was only adsorption capacity, but now many factors were introduced in order to study an effective dye adsorbent ( $\mathrm{pH}$, kinetic rate, ionic strength, adsorbent's dosage, etc.). More attention was also given on the nature and especially porosity of adsorbents, creating a new promising class of nanomaterials. However, apart from all of the above, the main drawback of the already published dye-adsorption studies is that their use is still in the laboratory stage mostly without pilot studies or commercialization. Limited attempts for detailed economic and market analyses are available. The main future target of market is to move the dye adsorption process to an industrial scale. It is relatively less difficult to demonstrate it in a laboratory; it is a little more challenging to demonstrate it at a pilot scale, but to really increase it to a large scale would call for a significant financial and technological effort.

\section{Acknowledgments}

This work has been completely financed by Technological Educational Institute of Kavala (President: A.Ch. Mitropoulos). 


\section{Conflicts of Interest}

The authors declare no conflict of interest.

\section{References}

1. Sharma, P.; Kaur, H.; Sharma, M.; Sahore, V. A review on applicability of naturally available adsorbents for the removal of hazardous dyes from aqueous waste. Environ. Monit. Assess. 2011, 183, 151-195.

2. Attia, A.A.; Girgis, B.S.; Fathy, N.A. Removal of methylene blue by carbons derived from peach stones by $\mathrm{H}_{3} \mathrm{PO}_{4}$ activation: Batch and column studies. Dye. Pigment. 2008, 76, 282-289.

3. Namasivayam, C.; Kavitha, D. Removal of Congo Red from water by adsorption onto activated carbon prepared from coir pith, an agricultural solid waste. Dye. Pigment. 2002, 54, 47-58.

4. Goyal, M.; Singh, S.; Bansal, R.C. Equilibrium and dynamic adsorption of methylene blue from aqueous solutions by surface modified activated carbons. Carbon Sci. 2004, 5, 170-179.

5. Khattri, S.D.; Singh, M.K. Colour removal from aqueous solutions by adsorption. Indian J. Chem. Technol. 1998, 5, 230-234.

6. Karadag, D.; Akgul, E.; Tok, S.; Erturk, F.; Kaya, M.A.; Turan, M. Basic and reactive dye removal using natural and modified zeolites. J. Chem. Eng. Data 2007, 52, 2436-2441.

7. Karcher, S.; Kornmüller, A.; Jekel, M. Anion exchange resins for removal of reactive dyes from textile wastewaters. Water Res. 2002, 36, 4717-4724.

8. Purkait, M.K.; DasGupta, S.; De, S. Adsorption of eosin dye on activated carbon and its surfactant based desorption. J. Environ. Manag. 2005, 76, 135-142.

9. Pearce, C.I.; Lloyd, J.R.; Guthrie, J.T. The removal of colour from textile wastewater using whole bacterial cells: A review. Dye. Pigment. 2003, 58, 179-196.

10. McMullan, G.; Meehan, C.; Conneely, A.; Kirby, N.; Robinson, T.; Nigam, P.; Banat, I.M.; Marchant, R.; Smyth, W.F. Microbial decolourisation and degradation of textile dyes. Appl. Microbiol. Biotechnol. 2001, 56, 81-87.

11. Robinson, T.; McMullan, G.; Marchant, R.; Nigam, P. Remediation of dyes in textile effluent: A critical review on current treatment technologies with a proposed alternative. Bioresour. Technol. 2001, 77, 247-255.

12. O’Neill, C.; Hawkes, F.R.; Hawkes, D.L.; Lourenço, N.D.; Pinheiro, H.M.; Delée, W. Colour in textile effluents-Sources, measurement, discharge consents and simulation: A review. J. Chem. Technol. Biotechnol. 1999, 74, 1009-1018.

13. Vandevivere, P.C.; Bianchi, R.; Verstraete, W. Treatment and reuse of wastewater from the textile wet-processing industry: Review of emerging technologies. J. Chem. Technol. Biotechnol. 1998, 72, 289-302.

14. Kumar, M.N.V.R.; Sridhari, T.R.; Bhavani, K.D.; Dutta, P.K. Trends in color removal from textile mill effluents. Colourage 1998, 45, 25-34.

15. Sun, Q.; Yang, L. The adsorption of basic dyes from aqueous solution on modified peat-resin particle. Water Res. 2003, 37, 1535-1544. 
16. Mishra, G.; Tripathy, M. A critical review of the treatments for decolourization of textile effluent. Colourage 1993, 40, 35-38.

17. Zollinger, H. Color Chemistry: Synthesis, Properties and Applications of Organic Dyes and Pigments; VCH: Weinheim, Germany, 1987.

18. Chiou, M.S.; Ho, P.Y.; Li, H.Y. Adsorption of anionic dyes in acid solutions using chemically cross-linked chitosan beads. Dye. Pigment. 2004, 60, 69-84.

19. Blackburn, R.S. Natural polysaccharides and their interactions with dye molecules: Applications in effluent treatment. Environ. Sci. Technol. 2004, 38, 4905-4909.

20. Chiou, M.S.; Li, H.Y. Adsorption behavior of reactive dye in aqueous solution on chemical cross-linked chitosan beads. Chemosphere 2003, 50, 1095-1105.

21. Allègre, C.; Moulin, P.; Maisseu, M.; Charbit, F. Treatment and reuse of reactive dyeing effluents. J. Membr. Sci. 2006, 269, 15-34.

22. Robinson, T.; Chandran, B.; Nigam, P. Studies on desorption of individual textile dyes and a synthetic dye effluent from dye-adsorbed agricultural residues using solvents. Bioresour. Technol. 2002, 84, 299-301.

23. Robinson, T.; Chandran, B.; Nigam, P. Removal of dyes from a synthetic textile dye effluent by biosorption on apple pomace and wheat straw. Water Res. 2002, 36, 2824-2830.

24. Crini, G. Non-conventional low-cost adsorbents for dye removal: A review. Bioresour. Technol. 2006, 97, 1061-1085.

25. Fiorentin, L.D.; Trigueros, D.E.G.; Módenes, A.N.; Espinoza-Quiñones, F.R.; Pereira, N.C.; Barros, S.T.D.; Santos, O.A.A. Biosorption of reactive blue 5G dye onto drying orange bagasse in batch system: Kinetic and equilibrium modeling. Chem. Eng. J. 2010, 163, 68-77.

26. Kaushik, C.P.; Tuteja, R.; Kaushik, N.; Sharma, J.K. Minimization of organic chemical load in direct dyes effluent using low cost adsorbents. Chem. Eng. J. 2009, 155, 234-240.

27. Konaganti, V.K.; Kota, R.; Patil, S.; Madras, G. Adsorption of anionic dyes on chitosan grafted poly(alkyl methacrylate)s. Eng. J. 2010, 158, 393-401.

28. Kyzas, G.Z. A decolorization technique with spent "Greek coffee" grounds as zero-cost adsorbents for industrial textile wastewaters. Materials 2012, 5, 2069-2087.

29. Kyzas, G.Z.; Lazaridis, N.K.; Mitropoulos, A.C. Removal of dyes from aqueous solutions with untreated coffee residues as potential low-cost adsorbents: Equilibrium, reuse and thermodynamic approach. Chem. Eng. J. 2012, 189-190, 148-159.

30. Kyzas, G.Z.; Kostoglou, M.; Vassiliou, A.A.; Lazaridis, N.K. Treatment of real effluents from dyeing reactor: Experimental and modeling approach by adsorption onto chitosan. Chem. Eng. J. 2011, 168, 577-585.

31. Chapman, A.C.; Siebold, A. On the application of adsorption to the detection and separation of certain dyes. Analyst 1912, 37, 339-345.

32. Davis, P.P.; France, W.G. Adsorption at crystal-solution interfaces. VIII. Influence of dyes and other organic compounds on the crystal habit of barium and lead nitrates. J. Phys. Chem. 1936, $40,81-87$.

33. Weinland Sr, L.A.; France, W.G. Adsorption at crystal solution interfaces. VI. Macroscopic sodium nitrate crystals grown in the presence of dyes and other foreign materials. J. Phys. Chem. 1932, 36, 2832-2839. 
34. Kolthoff, I.M.; von Fischer, W.; Rosenblum, C. The adsorption of wool violet (4BN) by lead sulfate and the influence of the adsorbed dye on the speed of kinetic exchange. J. Am. Chem. Soc. 1934, 56, 832-836.

35. Gibby, C.W.; Argument, C. Adsorption at the interface between two fluids. Part III. The adsorption of five dyes at a mercury-water interface. J. Chem. Soc. 1940, 596-600.

36. Ewing, W.W.; Liu, F.W.J. Adsorption of dyes from aqueous solutions on pigments. J. Colloid Sci. 1953, 8, 204-213.

37. Whetstone, J. The adsorption of dyes by crystals. Discuss. Faraday Soc. 1954, 16, 132-140.

38. Haldeman, R.G.; Emmett, P.H. Specific adsorption of alkyl orange dyes on silica gel. J. Phys. Chem. 1955, 59, 1039-1043.

39. Prasad, R.; Dey, A.K. Adsorption of dyestuffs by hydrous thorium oxide: Heat of adsorption of the dyes by various samples of the hydroxide. Kolloid Z. Z. Polym. 1962, 183, 153-155.

40. Brooks, C.S. Mechanism of methylene blue dye adsorption on siliceous minerals. Kolloid Z. $Z$. Polym. 1964, 199, 31-36.

41. Padday, J.F. Adsorption of cyanine dyes at silver-halide surfaces. Trans. Faraday Soc. 1964, 60, 1325-1334.

42. Padday, J.F.; Wickham, R.S. Adsorption of cyanine dyes at silver halide surfaces: Part 2-Spectral properties and coverage. Trans. Faraday Soc. 1966, 62, 1283-1295.

43. Davis, G.A.; Joyce, I.H.; Worrall, W.E. Effect of surface characteristics of ceramic raw materials on dye adsorption. Brit. Cer. Soc-Trans. 1969, 68, 215-221.

44. Iyer, S.R.S.; Chanekar, A.S.; Srinivasan, G. Adsorption of dyes on water-swollen and non-swelling solid substreates. ACS Symp. Ser. 1974, 79-95.

45. Rock, S.L.; Stevens, B.W. Polymeric adsorption ion exchange process for decolorizing dye waste streams. Text. Chem. Color. 1975, 7, 57-59.

46. Sethuraman, V.V.; Raymahashay, B.C. Color removal by clays. Kinetic study of adsorption of cationic and anionic dyes. Environ. Sci. Technol. 1975, 9, 1139-1140.

47. Mitchell, M.; Ernst, W.R.; Lightsey, G.R.; Rasmussen, E.T.; Bagherzadeh, P. Adsorption of textile dyes by activated carbon produced from agricultural, municipal and industrial wastes. Bull. Environ. Contam. Toxicol. 1978, 19, 307-311.

48. McKay, G. Adsorption of acidic and basic dyes onto activated carbon in fluidised beds. Chem. Eng. Res. Des. 1983, 61, 29-36.

49. McKay, G.; Allen, S.J.; McConvey, I.F. The adsorption of dyes from solution-Equilibrium and column studies. Water Air Soil Poll. 1984, 21, 127-139.

50. McConvey, I.F.; McKay, G. Mass transfer model for the adsorption of basic dyes on woodmeal in agitated batch adsorbers. Chem. Eng. Process. 1985, 19, 267-275.

51. McKay, G.; McConvey, I.F. Adsorption of acid dye onto woodmeal by solid diffusional mass transfer. Chem. Eng. Process. 1985, 19, 287-295.

52. McKay, G.; Otterburn, M.S.; Aga, J.A. Pore diffusion and external mass transport during dye adsorption on to Fuller's earth and silica. J. Chem. Technol. Biotechnol. 1987, 37, 247-256.

53. Morita, Z.; Tanaka, T.; Motomura, H. Diffusion/adsorption model of cellulose dyeing. II. Ordinary cellulose-direct dye system. J. Appl. Polym. Sci. 1985, 30, 3697-3705. 
54. Babel, S.; Kurniawan, T.A. Low-cost adsorbents for heavy metals uptake from contaminated water: A review. J. Hazard. Mater. 2003, 97, 219-243.

55. Ramakrishna, K.R.; Viraraghavan, T. Dye removal using low cost adsorbents. Water Sci. Technol. 1997, 36, 189-196.

56. Wang, S.; Zhu, Z.H. Effects of acidic treatment of activated carbons on dye adsorption. Dye. Pigment. 2007, 75, 306-314.

57. Nakagawa, K.; Namba, A.; Mukai, S.R.; Tamon, H.; Ariyadejwanich, P.; Tanthapanichakoon, W. Adsorption of phenol and reactive dye from aqueous solution on activated carbons derived from solid wastes. Water Res. 2004, 38, 1791-1798.

58. Li, Q.; Snoeyink, V.L.; Campos, C.; Mariñas, B.J. Displacement effect of NOM on atrazine adsorption by PACs with different pore size distributions. Environ. Sci. Technol. 2002, 36, 1510-1515.

59. Choy, K.K.H.; Porter, J.F.; McKay, G. Langmuir isotherm models applied to the multicomponent sorption of acid dyes from effluent onto activated carbon. J. Chem. Eng. Data 2000, 45, 575-584.

60. Karanfil, T.; Dastgheib, S.A.; Mauldin, D. Exploring molecular sieve capabilities of activated carbon fibers to reduce the impact of NOM preloading on trichloroethylene adsorption. Environ. Sci. Technol. 2006, 40, 1321-1327.

61. Kannan, N.; Sundaram, M.M. Kinetics and mechanism of removal of methylene blue by adsorption on various carbons-A comparative study. Dye. Pigment. 2001, 51, 25-40.

62. Jirankova, H.; Cakl, J.; Markvartova, O.; Dolecek, P. Combined membrane process at wastewater treatment. Sep. Purif. Technol. 2007, 58, 299-303.

63. McKay, G.; Sze, M.F.F. The removal of organic pollutants from industrial effluents via tapered bed adsorption columns. Int. J. Environ. Technol. Manag.2008, 9, 20-33.

64. Al-Degs, Y.S.; El-Barghouthi, M.I.; El-Sheikh, A.H.; Walker, G.M. Effect of solution pH, ionic strength, and temperature on adsorption behavior of reactive dyes on activated carbon. Dye. Pigment. 2008, 77, 16-23.

65. Nassar, M.M.; Magdy, Y.H. Removal of different basic dyes from aqueous solutions by adsorption on palm-fruit bunch particles. Chem. Eng. J. 1997, 66, 223-226.

66. Pereira, M.F.R.; Soares, S.F.; Órfão, J.J.M.; Figueiredo, J.L. Adsorption of dyes on activated carbons: Influence of surface chemical groups. Carbon 2003, 41, 811-821.

67. Demirbas, A. Agricultural based activated carbons for the removal of dyes from aqueous solutions: A review. J. Hazard. Mater. 2009, 167, 1-9.

68. Sharma, N.; Tiwari, D.P.; Singh, S.K. Decolourisation of synthetic dyes by agricultural waste-A review. Int. J. Sci. Eng. Res. 2012, 3, 1-10.

69. Annadurai, G.; Juang, R.S.; Lee, D.J. Use of cellulose-based wastes for adsorption of dyes from aqueous solutions. J. Hazard. Mater. 2002, 92, 263-274.

70. Banat, F.; Al-Asheh, S.; Al-Makhadmeh, L. Evaluation of the use of raw and activated date pits as potential adsorbents for dye containing waters. Process Biochem. 2003, 39, 193-202.

71. Namasivayam, C.; Dinesh Kumar, M.; Selvi, K.; Ashruffunissa Begum, R.; Vanathi, T.; Yamuna, R.T. 'Waste' coir pith-A potential biomass for the treatment of dyeing wastewaters. Biomass Bioenergy 2001, 21, 477-483. 
72. Khattri, S.D.; Singh, M.K. Colour removal from synthetic dye wastewater using a bioadsorbent. Water Air Soil Poll. 2000, 120, 283-294.

73. Garg, V.K.; Gupta, R.; Yadav, A.B.; Kumar, R. Dye removal from aqueous solution by adsorption on treated sawdust. Bioresour. Technol. 2003, 89, 121-124.

74. Bagreev, A.; Rahman, H.; Bandosz, T.J. Thermal regeneration of a spent activated carbon previously used as hydrogen sulfide adsorbent. Carbon 2001, 39, 1319-1326.

75. Sabio, E.; González, E.; González, J.F.; González-García, C.M.; Ramiro, A.; Gañan, J. Thermal regeneration of activated carbon saturated with p-nitrophenol. Carbon 2004, 42, 2285-2293.

76. San Miguel, G.; Lambert, S.D.; Graham, N.J.D. The regeneration of field-spent granular-activated carbons. Water Res. 2001, 35, 2740-2748.

77. Álvarez, P.M.; Beltrán, F.J.; Gómez-Serrano, V.; Jaramillo, J.; Rodríguez, E.M. Comparison between thermal and ozone regenerations of spent activated carbon exhausted with phenol. Water Res. 2004, 38, 2155-2165.

78. Martin, R.J.; Ng, W.J. The repeated exhaustion and chemical regeneration of activated carbon. Water Res. 1987, 21, 961-965.

79. Aizpuru, A.; Malhautier, L.; Roux, J.C.; Fanlo, J.L. Biofiltration of a mixture of volatile organic compounds on granular activated carbon. Biotechnol. Bioeng. 2003, 83, 479-488.

80. Narbaitz, R.M.; Karimi-Jashni, A. Electrochemical regeneration of granular activated carbons loaded with phenol and natural organic matter. Environ. Technol. 2008, 30, 27-36.

81. Lim, J.-L.; Okada, M. Regeneration of granular activated carbon using ultrasound. Ultrason. Sonochem. 2005, 12, 277-282.

82. Shende, R.V.; Mahajani, V.V. Wet oxidative regeneration of activated carbon loaded with reactive dye. Waste Manag. 2002, 22, 73-83.

83. Wu, F.C.; Tseng, R.L.; Juang, R.S. Kinetic modeling of liquid-phase adsorption of reactive dyes and metal ions on chitosan. Water Res. 2001, 35, 613-618.

84. Wu, F.C.; Tseng, R.L.; Juang, R.S. Enhanced abilities of highly swollen chitosan beads for color removal and tyrosinase immobilization. J. Hazard. Mater. 2001, 81, 167-177.

85. Wu, F.C.; Tseng, R.L.; Juang, R.S. Comparative adsorption of metal and dye on flake-and bead-types of chitosans prepared from fishery wastes. J. Hazard. Mater. 2000, 73, 63-75.

86. Annadurai, G. Design of optimum response surface experiments for adsorption of direct dye on chitosan. Bioprocess. Eng. 2000, 23, 451-455.

87. Annadurai, G. Adsorption of basic dye on strongly chelating polymer: Batch kinetics studies. Iran. Polym. J. 2002, 11, 237-244.

88. Annadurai, G.; Lee, D.J.; Juang, R.S. Box-Behnken studies on dye removal from water using chitosan and activated carbon adsorbents. J. Chin. Inst. Chem. Eng. 2000, 31, 609-615.

89. Crini, G.; Martel, B.; Torri, G. Adsorption of C.I. Basic Blue 9 on chitosan-based materials. Int. J. Environ. Pollut. 2008, 34, 451-465.

90. Uzun, I. Kinetics of the adsorption of reactive dyes by chitosan. Dye. Pigment. 2006, 70, 76-83.

91. Uzun, I.; Güzel, F. Kinetics and thermodynamics of the adsorption of some dyestuffs and p-nitrophenol by chitosan and MCM-chitosan from aqueous solution. J. Colloid Interface Sci. 2004, 274, 398-412. 
92. Uzun, I.; Güzel, F. External mass transfer studies during the adsorptions of some dyestuffs and p-nitrophenol onto chitosan from aqueous solution. Turk. J. Chem. 2004, 28, 731-740.

93. Uzun, I.; Güzel, F. Rate studies on the adsorption of some dyestuffs and p-nitrophenol by chitosan and monocarboxymethylated(mcm)-chitosan from aqueous solution. J. Hazard. Mater. 2005, 118, 141-154.

94. Crini, G. Recent developments in polysaccharide-based materials used as adsorbents in wastewater treatment. Prog. Polym. Sci. 2005, 30, 38-70.

95. Kim, T.Y.; Cho, S.Y. Adsorption equilibria of reactive dye onto highly polyaminated porous chitosan beads. Korean J. Chem. Eng. 2005, 22, 691-696.

96. Lima, I.S.; Ribeiro, E.S.; Airoldi, C. The use of chemically modified chitosan with succinic anhydride in the methylene blue adsorption. Quím. Nova 2006, 29, 501-506.

97. Wong, Y.C.; Szeto, Y.S.; Cheung, W.H.; McKay, G. Equilibrium studies for acid dye adsorption onto chitosan. Langmuir 2003, 19, 7888-7894.

98. Wong, Y.C.; Szeto, Y.S.; Cheung, W.H.; McKay, G. Adsorption of acid dyes on chitosan-Equilibrium isotherm analyses. Process Biochem. 2004, 39, 693-702.

99. Wong, Y.C.; Szeto, Y.S.; Cheung, W.H.; McKay, G. Pseudo-first-order kinetic studies of the sorption of acid dyes onto chitosan. J. Appl. Polym. Sci. 2004, 92, 1633-1645.

100. Gibbs, G.; Tobin, J.M.; Guibal, E. Sorption of Acid Green 25 on chitosan: Influence of experimental parameters on uptake kinetics and sorption isotherms. J. Appl. Polym. Sci. 2003, 90, 1073-1080.

101. Gibbs, G.; Tobin, J.M.; Guibal, E. Influence of chitosan preprotonation on Reactive Black 5 sorption isotherms and kinetics. Ind. Eng. Chem. Res. 2004, 43, 1-11.

102. Guibal, E.; McCarrick, P.; Tobin, J.M. Comparison of the sorption of anionic dyes on activated carbon and chitosan derivatives from dilute solutions. Sep. Sci. Technol. 2003, 38, 3049-3073.

103. Guibal, E.; Touraud, E.; Roussy, J. Chitosan interactions with metal ions and dyes: Dissolved-state vs. solid-state application. World J. Microbiol. Biotechnol. 2005, 21, 913-920.

104. Crini, G.; Gimbert, F.; Robert, C.; Martel, B.; Adam, O.; Morin-Crini, N.; de Giorgi, F.; Badot, P.M. The removal of Basic Blue 3 from aqueous solutions by chitosan-based adsorbent: Batch studies. J. Hazard. Mater. 2008, 153, 96-106.

105. Prabaharan, M.; Mano, J.F. Chitosan derivatives bearing cyclodextrin cavitiesas novel adsorbent matrices. Carbohydr. Polym. 2006, 63, 153-166.

106. Jayakumar, R.; Prabaharan, M.; Reis, R.L.; Mano, J.F. Graft copolymerized chitosan-Present status and applications. Carbohydr. Polym. 2005, 62, 142-158.

107. Chao, A.-C.; Shyu, S.-S.; Lin, Y.-C.; Mi, F.-L. Enzymatic grafting of carboxyl groups on to chitosan-To confer on chitosan the property of a cationic dye adsorbent. Bioresour. Technol. 2004, 91, 157-162.

108. Shimizu, Y.; Tanigawa, S.; Saito, Y.; Nakamura, T. Synthesis of chemically modified chitosans with a higher fatty acid glycidyl and their adsorption abilities for anionic and cationic dyes. J. Appl. Polym. Sci. 2005, 96, 2423-2428.

109. Gaffar, M.A.; El-Rafie, S.M.; El-Tahlawy, K.F. Preparation and utilization of ionic exchange resin via graft copolymerization of $\beta-\mathrm{CD}$ itaconate with chitosan. Carbohyd. Polym. 2004, 56, 387-396. 
110. Martel, B.; Devassine, M.; Crini, G.; Weltrowski, M.; Bourdonneau, M.; Morcellet, M. Preparation and sorption properties of a $\beta$-cyclodextrin-linked chitosan derivative. J. Polym. Sci. A Polym. Chem. 2001, 39, 169-176.

111. Cestari, A.R.; Vieira, E.F.S.; dos Santos, A.G.P.; Mota, J.A.; de Almeida, V.P. Adsorption of anionic dyes on chitosan beads. 1. The influence of the chemical structures of dyes and temperature on the adsorption kinetics. J. Colloid Interface Sci. 2004, 280, 380-386.

112. Chiou, M.S.; Ho, P.Y.; Li, H.Y. Adsorption behavior of dye AAVN and RB4 in acid solutions on chemically cross-linked Chitosan beads. J. Chin. Inst. Chem. Eng. 2003, 34, 625-634.

113. Chiou, M.S.; Kuo, W.S.; Li, H.Y. Removal of reactive dye from wastewater by adsorption using ECH cross-linked chitosan beads as medium. J. Environ. Sci. Health A Toxic/Hazard. Subst. Environ. Eng. 2003, 38, 2621-2631.

114. Rafatullah, M.; Sulaiman, O.; Hashim, R.; Ahmad, A. Adsorption of methylene blue on low-cost adsorbents: A review. J. Hazard. Mater. 2010, 177, 70-80.

115. Franca, A.S.; Oliveira, L.S.; Ferreira, M.E. Kinetics and equilibrium studies of methylene blue adsorption by spent coffee grounds. Desalination 2009, 249, 267-272.

116. Aksu, Z.; Isoglu, I.A. Use of agricultural waste sugar beet pulp for the removal of Gemazol turquoise blue-G reactive dye from aqueous solution. J. Hazard. Mater. 2006, 137, 418-430.

117. Gong, R.; Ding, Y.; Li, M.; Yang, C.; Liu, H.; Sun, Y. Utilization of powdered peanut hull as biosorbent for removal of anionic dyes from aqueous solution. Dye. Pigment. 2005, 64, 187-192.

118. Lakshmi, U.R.; Srivastava, V.C.; Mall, I.D.; Lataye, D.H. Rice husk ash as an effective adsorbent: Evaluation of adsorptive characteristics for Indigo Carmine dye. J. Environ. Manag. 2009, 90, 710-720.

119. Gong, R.; Sun, Y.; Chen, J.; Liu, H.; Yang, C. Effect of chemical modification on dye adsorption capacity of peanut hull. Dye. Pigment. 2005, 67, 175-181.

120. Gong, R.; Li, M.; Yang, C.; Sun, Y.; Chen, J. Removal of cationic dyes from aqueous solution by adsorption on peanut hull. J. Hazard. Mater. 2005, 121, 247-250.

121. Santhy, K.; Selvapathy, P. Removal of reactive dyes from wastewater by adsorption on coir pith activated carbon. Bioresour. Technol. 2006, 97, 1329-1336.

122. Kavitha, D.; Namasivayam, C. Experimental and kinetic studies on methylene blue adsorption by coir pith carbon. Bioresour. Technol. 2007, 98, 14-21.

123. Namasivayam, C.; Sangeetha, D. Recycling of agricultural solid waste, coir pith: Removal of anions, heavy metals, organics and dyes from water by adsorption onto $\mathrm{ZnCl}_{2}$ activated coir pith carbon. J. Hazard. Mater. 2006, 135, 449-452.

124. Rahman, I.A.; Saad, B.; Shaidan, S.; Sya Rizal, E.S. Adsorption characteristics of malachite green on activated carbon derived from rice husks produced by chemical-thermal process. Bioresour. Technol. 2005, 96, 1578-1583.

125. Guo, Y.; Zhang, H.; Tao, N.; Liu, Y.; Qi, J.; Wang, Z.; Xu, H. Adsorption of malachite green and iodine on rice husk-based porous carbon. Mater. Chem. Phys. 2003, 82, 107-115.

126. Han, R.; Ding, D.; Xu, Y.; Zou, W.; Wang, Y.; Li, Y.; Zou, L. Use of rice husk for the adsorption of congo red from aqueous solution in column mode. Bioresour. Technol. 2008, 99, 2938-2946.

127. Uddin, M.T.; Islam, M.A.; Mahmud, S.; Rukanuzzaman, M. Adsorptive removal of methylene blue by tea waste. J. Hazard. Mater. 2009, 164, 53-60. 
128. Ahmad, R. Studies on adsorption of crystal violet dye from aqueous solution onto coniferous pinus bark powder (CPBP). J. Hazard. Mater. 2009, 171, 767-773.

129. Khaled, A.; Nemr, A.E.; El-Sikaily, A.; Abdelwahab, O. Removal of Direct N Blue-106 from artificial textile dye effluent using activated carbon from orange peel: Adsorption isotherm and kinetic studies. J. Hazard. Mater. 2009, 165, 100-110.

130. Khattri, S.D.; Singh, M.K. Removal of malachite green from dye wastewater using neem sawdust by adsorption. J. Hazard. Mater. 2009, 167, 1089-1094.

131. Elizalde-González, M.P.; Hernández-Montoya, V. Guava seed as an adsorbent and as a precursor of carbon for the adsorption of acid dyes. Bioresour. Technol. 2009, 100, 2111-2117.

132. Tanyildizi, M.T. Modeling of adsorption isotherms and kinetics of reactive dye from aqueous solution by peanut hull. Chem. Eng. J. 2011, 168, 1234-1240.

133. Abdelwahab, O. Evaluation of the use of loofa activated carbons as potential adsorbents for aqueous solutions containing dye. Desalination 2008, 222, 357-367.

134. Demirbas, E.; Kobya, M.; Sulak, M.T. Adsorption kinetics of a basic dye from aqueous solutions onto apricot stone activated carbon. Bioresour. Technol. 2008, 99, 5368-5373.

135. Doulati Ardejani, F.; Badii, K.; Limaee, N.Y.; Shafaei, S.Z.; Mirhabibi, A.R. Adsorption of Direct Red 80 dye from aqueous solution onto almond shells: Effect of $\mathrm{pH}$, initial concentration and shell type. J. Hazard. Mater. 2008, 151, 730-737.

136. Kumar, K.V. Optimum sorption isotherm by linear and non-linear methods for malachite green onto lemon peel. Dye. Pigment. 2007, 74, 595-597.

137. Mall, I.D.; Srivastava, V.C.; Agarwal, N.K. Removal of Orange-G and Methyl Violet dyes by adsorption onto bagasse fly ash-Kinetic study and equilibrium isotherm analyses. Dye. Pigment. 2006, 69, 210-223.

138. Wang, L.; Zhang, J.; Zhao, R.; Li, C.; Li, Y.; Zhang, C. Adsorption of basic dyes on activated carbon prepared from Polygonum orientale Linn: Equilibrium, kinetic and thermodynamic studies. Desalination 2010, 254, 68-74.

139. Srinivasan, A.; Viraraghavan, T. Decolorization of dye wastewaters by biosorbents: A review. J. Environ. Manag. 2010, 91, 1915-1929.

140. Fu, Y.; Viraraghavan, T. Fungal decolorization of dye wastewaters: A review. Bioresour. Technol. 2001, 79, 251-262.

141. Fu, Y.; Viraraghavan, T. Removal of CI Acid Blue 29 from an aqueous solution by Aspergillus niger. Aatcc Rev. 2001, 1, 36-40.

142. Bilgic, H.; Gokcay, C.F.; Hasirci, N. Color removal by white-rot fungi. Glob. Environ. Biotechnol. 1997, 66, 211-222.

143. Cammarota, M.C.; Sant'Anna, G.L., Jr. Decolorization of kraft bleach plant E1 stage effluent in a fungal bioreactor. Environ. Technol. 1992, 13, 65-71.

144. Lankinen, V.P.; Inkeroinen, M.M.; Pellinen, J.; Hatakka, A.I. The onset of lignin-modifying enzymes, decrease of AOX and color removal by white-rot fungi grown on bleach plant effluents. Water Sci. Technol. 1991, 24, 189-198.

145. Tatarko, M.; Bumpus, J.A. Biodegradation of Congo Red by Phanerochaete chrysosporium. Water Res. 1998, 32, 1713-1717. 
146. Faraco, V.; Pezzella, C.; Miele, A.; Giardina, P.; Sannia, G. Bio-remediation of colored industrial wastewaters by the white-rot fungi Phanerochaete chrysosporium and Pleurotus ostreatus and their enzymes. Biodegradation 2009, 20, 209-220.

147. Gomaa, O.M.; Linz, J.E.; Reddy, C.A. Decolorization of Victoria blue by the white rot fungus, Phanerochaete chrysosporium. World J. Microbiol. Biotechnol. 2008, 24, 2349-2356.

148. Sharma, P.; Singh, L.; Dilbaghi, N. Biodegradation of Orange II dye by Phanerochaete chrysosporium in simulated wastewater. J. Sci. Ind. Res. 2009, 68, 157-161.

149. Young, L.; Yu, J. Ligninase-catalysed decolorization of synthetic dyes. Water Res. 1997, 31, $1187-1193$.

150. Fu, Y.; Viraraghavan, T. Removal of a dye from an aqueous solution by the fungus Aspergillus niger. Water Qual. Res. J. Can. 2000, 35, 95-111.

151. Fu, Y.; Viraraghavan, T. Removal of Congo Red from an aqueous solution by fungus Aspergillus niger. Adv. Environ. Res. 2002, 7, 239-247.

152. Zhou, J.L.; Banks, C.J. Removal of humic acid fractions by Rhizopus arrhizus: Uptake and kinetic studies. Environ. Technol. 1991, 12, 859-869.

153. Gallagher, K.A.; Healy, M.G.; Allen, S.J. Biosorption of synthetic dye and metal ions from aqueous effluents using fungal biomass. Glob. Environ. Biotechnol. 1997, 27-50.

154. Raghukumar, C.; Chandramohan, D.; Michel, F.C., Jr.; Reddy, C.A. Degradation of lignin and decolorization of paper mill bleach plant effluent (BPE) by marine fungi. Biotechnol. Lett. 1996, 18, 105-106.

155. Kaushik, P.; Malik, A. Fungal dye decolourization: Recent advances and future potential. Environ. Int. 2009, 35, 127-141.

156. Singh, H. Mycoremediation: Fungal Bioremediation; John Wiley \& Sons Inc: Hoboken, NJ, USA, 2006.

157. Fu, Y.; Viraraghavan, T. Dye biosorption sites in Aspergillus niger. Bioresour. Technol. 2002, $82,139-145$.

158. Forgacs, E.; Cserháti, T.; Oros, G. Removal of synthetic dyes from wastewaters: A review. Environ. Int. 2004, 30, 953-971.

159. Won, S.W.; Choi, S.B.; Yun, Y.-S. Interaction between protonated waste biomass of Corynebacterium glutamicum and anionic dye Reactive Red 4. Colloid Surface A Physicochem. Eng. Asp. 2005, 262, 175-180.

160. Beveridge, T.J. Ultrastructure, chemistry, and function of the bacterial wall. Int. Rev. Cytol. 1981, 72, 229-317.

161. Dijkstra, A.J.; Keck, W. Peptidoglycan as a barrier to transenvelope transport. J. Bacteriol. 1996, $178,5555-5562$.

162. Beveridge, T.J. Structures of gram-negative cell walls and their derived membrane vesicles. J. Bacteriol. 1999, 181, 4725-4733.

163. Hu, T.L., Removal of reactive dyes from aqueous solution by different bacterial genera. Water Sci. Technol. 1996, 34, 89-95.

164. Van der Wal, A.; Norde, W.; Zehnder, A.J.B.; Lyklema, J. Determination of the total charge in the cell walls of Gram-positive bacteria. Colloids Surface B Biointerfaces 1997, 9, 81-100. 
165. Vijayaraghavan, K.; Yun, Y.-S. Utilization of fermentation waste (Corynebacterium glutamicum) for biosorption of Reactive Black 5 from aqueous solution. J. Hazard. Mater. 2007, 141, 45-52.

166. Şatiroğlu, N.; Yalçinkaya, Y.; Denizli, A.; Arica, M.Y.; Bektaş, S.; Genç, Ö. Application of $\mathrm{NaOH}$ treated Polyporus versicolor for removal of divalent ions of Group IIB elements from synthetic wastewater. Process Biochem. 2002, 38, 65-72.

167. Özer, A.; Akkaya, G.; Turabik, M. The removal of Acid Red 274 from wastewater: Combined biosorption and biocoagulation with Spirogyra rhizopus. Dye. Pigment. 2006, 71, 83-89.

168. Shukla, A.; Zhang, Y.H.; Dubey, P.; Margrave, J.L.; Shukla, S.S. The role of sawdust in the removal of unwanted materials from water. J. Hazard. Mater. 2002, 95, 137-152.

169. Venkata Mohan, S.; Chandrasekhar Rao, N.; Krishna Prasad, K.; Karthikeyan, J. Treatment of simulated Reactive Yellow 22 (Azo) dye effluents using Spirogyra species. Waste Manag. 2002, $22,575-582$.

170. Wu, G.; Koliadima, A.; Her, Y.S.; Matijević, E. Adsorption of dyes on nanosize modified silica particles. J. Colloid Interface Sci. 1997, 195, 222-228.

171. Khan, M.S.; Ahmad, A.; Bangash, F.U.K.; Shah, S.S.; Khan, P. Removal of basic dye from aqueous solutions using nano scale zero valent iron (NZVI) as adsorbent. J. Chem. Soc. Pak. 2013, 35, 744-748.

172. Zarezadeh-Mehrizi, M.; Badiei, A.; Mehrabadi, A.R. Ionic liquid functionalized nanoporous silica for removal of anionic dye. J. Mol. Liq. 2013, 180, 95-100.

173. Mahmoodi, N.M. Nickel ferrite nanoparticle: Synthesis, modification by surfactant and dye removal ability. Water Air Soil Poll. 2013, 224.

174. Zhai, T.; Xie, S.; Lu, X.; Xiang, L.; Yu, M.; Li, W.; Liang, C.; Mo, C.; Zeng, F.; Luan, T.; Tong, Y. Porous $\operatorname{Pr}(\mathrm{OH})_{3}$ nanostructures as high-efficiency adsorbents for dye removal. Langmuir 2012, 28, 11078-11085.

175. Liu, P.; Zhang, L. Adsorption of dyes from aqueous solutions or suspensions with clay nano-adsorbents. Sep. Purif. Technol. 2007, 58, 32-39.

176. Cheung, W.H.; Szeto, Y.S.; McKay, G. Enhancing the adsorption capacities of acid dyes by chitosan nano particles. Bioresour. Technol. 2009, 100, 1143-1148.

177. Fan, L.; Luo, C.; Sun, M.; Qiu, H.; Li, X. Synthesis of magnetic $\beta$-cyclodextrin-chitosan/graphene oxide as nanoadsorbent and its application in dye adsorption and removal. Colloids Surface B Biointerfaces 2013, 103, 601-607.

178. Liao, M.H.; Wu, K.Y.; Chen, D.H. Fast removal of basic dyes by a novel magnetic nano-adsorbent. Chem. Lett. 2003, 32, 488-489.

179. Afkhami, A.; Moosavi, R. Adsorptive removal of Congo Red, a carcinogenic textile dye, from aqueous solutions by maghemite nanoparticles. J. Hazard. Mater. 2010, 174, 398-403.

180. Deng, J.H.; Zhang, X.R.; Zeng, G.M.; Gong, J.L.; Niu, Q.Y.; Liang, J. Simultaneous removal of $\mathrm{Cd}(\mathrm{II})$ and ionic dyes from aqueous solution using magnetic graphene oxide nanocomposite as an adsorbent. Chem. Eng. J. 2013, 226, 189-200.

181. Madrakian, T.; Afkhami, A.; Ahmadi, M. Adsorption and kinetic studies of seven different organic dyes onto magnetite nanoparticles loaded tea waste and removal of them from wastewater samples. Spectrochim. Acta A Mol. Biomol. Spectrosc. 2012, 99, 102-109. 
182. Ge, F.; Ye, H.; Li, M.M.; Zhao, B.X. Efficient removal of cationic dyes from aqueous solution by polymer-modified magnetic nanoparticles. Chem. Eng. J. 2012, 198-199, 11-17.

183. Wang, C.; Feng, C.; Gao, Y.; Ma, X.; Wu, Q.; Wang, Z. Preparation of a graphene-based magnetic nanocomposite for the removal of an organic dye from aqueous solution. Chem. Eng. J. 2011, 173, 92-97.

184. Gong, J.L.; Wang, B.; Zeng, G.M.; Yang, C.P.; Niu, C.G.; Niu, Q.Y.; Zhou, W.J.; Liang, Y. Removal of cationic dyes from aqueous solution using magnetic multi-wall carbon nanotube nanocomposite as adsorbent. J. Hazard. Mater. 2009, 164, 1517-1522.

185. Mishra, A.K.; Arockiadoss, T.; Ramaprabhu, S. Study of removal of azo dye by functionalized multi walled carbon nanotubes. Chem. Eng. J. 2010, 162, 1026-1034.

186. Jayarajan, M.; Arunachalam, R.; Annadurai, G. Agricultural wastes of Jackfruit peel nano-porous adsorbent for removal of Rhodamine dye. Asian J. Appl. Sci. 2011, 4, 263-270.

187. Tsezos, M. Biosorption of metals. The experience accumulated and the outlook for technology development. Hydrometallurgy 2001, 59, 241-243.

188. Wase, J.; Forster, C. Biosorbents for Metal Ions; Taylor \& Francis: London, UK, 1997.

189. Wang, J.; Chen, C. Biosorbents for heavy metals removal and their future. Biotechnol. Adv. 2009, 27, 195-226.

190. West, W.; Nightingale, P. Organizing for innovation: Towards successful translational research. Trends Biotechnol. 2009, 27, 558-561.

(C) 2013 by the authors; licensee MDPI, Basel, Switzerland. This article is an open access article distributed under the terms and conditions of the Creative Commons Attribution license (http://creativecommons.org/licenses/by/3.0/). 